\title{
Krystian Piotrowski*
}

\section{"Mimecstasy" of "Hexpression" Semiotic Explorations in Christine Brooke-Rose’s Amalgamemnon}

DOI: http://dx.doi.org/10.12775/LC.2020.035

\begin{abstract}
The article analyses the problematics of non-communication in Christine Brooke-Rose's Amalgamemnon (1984), paying special attention to intratextual realisations of absence and silence. Both read as parasemiotic signs of low indexicality and iconicity, they are nonetheless interpreted and conceptualised as a significant, meaning-laden device which merits further critical attention. BrookeRose's "semiotic explorations" - so clearly visible in her growing preoccupation with language and all things linguistic - testify to her interest in the limits of social intercourse. Experimenting with what is barely verbalisable, the author creates and employs a number of original discursive practices that at the same time deepen and enhance the reader's understanding of the characters in the novel as much as they complicate its coherent hermeneutic appraisal. Amalgamemnon is thus examined as a text unique to the British literary canon, being a sui generis anti-novel mixing and matching a complex, defragmented narrative, a historiographic study of ancient myths, a prescient analysis of dehumanising technology, as well as a pressing social commentary - all conjoined in an ambitious attempt at probing the boundaries of language and thought.
\end{abstract}

Keywords: silence, aporia, loss, trauma, experimental literature

\footnotetext{
* PhD candidate at the Doctoral School in the Humanities, Jagiellonian University in Kraków. His main academic pursuits include contemporary experimental writing, surfiction, life-writing, memory and affective studies, as well as corporeal feminism. His dissertation focuses on the conceptualisation of an affective poetics and somaesthetics in twentieth-century British avant-garde literature.

E-mail: krystian.piotrowski@doctoral.uj.edu.pl | ORCID: 0000-0003-4357-6467.
} 


\section{„Mimekstaza przekleńspresji” Eksploracje semiotyczne w Amalgamemnonie Christine Brooke-Rose}

Streszczenie: Artykuł analizuje problematykębraku komunikacji międzyludzkiejwAmalgamemnonie (1984) Christine Brooke-Rose, zwracając szczególną uwagę na wewnątrztekstowe przejawy nieobecności i ciszy. Pojmowane jako parasemiotyczne znaki o niskiej indeksowości i ikoniczności, są one interpretowane i konceptualizowane jako ważny i pełen znaczenia środek wyrazu, zasługujący na pogłębiony komentarz krytyczny. „Eksploracje semiotyczne” Brooke-Rose - tak wyraźnie przejawiające się w jej eksperymentach z językiem i wszystkim tym, co językowe - świadczą o jej zainteresowaniu ograniczeniami w ludzkiej komunikacji. Poświęcając uwagę temu, co wymyka się łatwej werbalizacji, autorka tworzy i stosuje szereg oryginalnych praktyk artystycznych, które z jednej strony pogłębiają zrozumienie czytelnika dla bohaterów jej powieści, lecz z drugiej - utrudniają spójną hermeneutyczną analizę całego dzieła. Amalgamemnon jest tym samym rozpatrywany jako tekst unikatowy dla brytyjskiego kanonu literackiego, będący iście niepowtarzalną anty-powieścią, łączącą w sobie wysoce zdefragmentaryzowaną narrację, historiograficzne studium starożytnych mitów, profetyczną analizę coraz to bardziej dehumanizującej technologii, a także istotny komentarz społeczny - wszystko to będące ambitną próbą zbadania granic języka i myśli ludzkiej.

Słowa kluczowe: cisza, aporia, strata, trauma, literatura eksperymentalna

Shape nothing, lips; be lovely-dumb:

It is the shut, the curfew sent

From there where all surrenders come

Which only makes you eloquent.

Gerard Manley Hopkins, "The Habit of Perfection”

aving laid bare the shortcomings of manifold exegetic paradigms and theories (particularly those developed by Roman Ingarden and E. D. Hirsch) in his seminal Nebulae of Discourse, Wojciech Kalaga negates the dichotomy between comprehension and interpretation. The latter, though constitutive and absolutely essential to any textual analysis, does nothing but actualise the semiotic interconnections between various signs that are present in a text ${ }^{1}$. In this sense, each act of interpretation unearths and brings to the fore elements that are always-already existent in discourse. It restrains the agency of the reader (as well as of what Stanley Fish would name "interpretative communities", which, after all, the said reader is a part of) as much as it restricts any exegete to base their arguments solely

\footnotetext{
1 In opposing paradigms, such as paninterpretationism espoused by Stanley Fish, the limits of a hermeneutic analysis determine the limits of any piece of writing, despite the fact that the reader, a homo interpretans, "is taught to think of himself as a transmitter of the best that had been thought and said by others, and his greatest fear is that he will stand charged of having substituted his own meaning for the meanings of which he is supposedly the guardian; his greatest fear is that he be found guilty of having interpreted" (Fish 1980: 355 ).
} 
on the intersemiotic connections between signs. "Il n'y a pas de hors-texte", one could still say, following Derrida. Consequently, "[s]igns exist in and through interpretation" (Kalaga 1997: 171), and they do so not in the least by the conscious effort of a person decoding any linguistic message but due to their inherent logic; in other words, "the sign exists not because it is actually used, understood, or interpreted by someone at a given moment, but because it is interpreted by another sign" (ibid.: 52). This topic was of great interest to Christine Brooke-Rose (1923-2012), as testified to not only by her most insightful academic analy$\operatorname{ses}^{2}$ but also her masterful and thoroughly original prose. Admittedly, her "semiotic explorations" - the search for meaning in sign systems - breached the boundaries of any conventional scientific study, mixing and subversively fusing interdisciplinary theories with a view towards a conceptualisation of some new quality, very often reaching far beyond the actual topic of her astute essayistic pieces ${ }^{3}$. Brooke-Rose's research and literary endeavours alike probed and scrutinised the limits of language and human (non)communication, with a special emphasis being laid on the "nebulous peripheries" of discursive practices and - to once more refer to Kalaga - "the nebular nature of texts and of human subjectivity" (1997: 218), where silence, aporia, and absence play a special role: both that of a "binder", bonding various discourses together, and a destabilising aberration normally looked down upon in any interpretative community. Their status as a sign is vastly problematic, yet they can be "verbalised" (or otherwise expressed) in discourse, and, as a consequence - decoded, interpreted, and conceptualised.

Brooke-Rose may well have "experimented with [the] capacity of virtually infinite semiosis of language and transposed it into her novels in various narrative techniques" (Bartha 2014: 1), but no text of hers showcases it better than her forgotten masterpiece, Amalgamemnon (1984). It is the first novel of her second tetralogy, which focuses predominantly on the problematics of language and unalike literary and scientific discourses but also on the fast-paced development of technology, drawing from and tapping into the tradition of an academic and campus novel, as did Brooke-Rose's previous tour-de-force of a book from 1975, Thru. Amalgamemnon, to refer somewhat flippantly to its title, is an amalgamation of disparate elements: of a story-driven narrative, of a historiographic study of ancient Greek myths, of relevant social commentary, but also of a prescient, visionary analysis of dehumanising technology or a feminist diatribe against inequality that stems from "[n]aïve dissatisfaction with the conventions" (Seed 1993: 250). All those elements, oftentimes constituted by and reflected in linguistic signs as well as their complex interrelations, illuminate one another and add up to a bigger picture. The imaginary axis around which everything revolves is the story of Mira Enketei, a professor of classics at some grand, albeit unnamed, university, who faces imminent termination of employment and - by extension her academic career. Mira's professional problems are mirrored in her private life, where she is also disregarded, belittled, or sexually harassed by her partner and other men whom

\footnotetext{
2 Suffice to mention A Grammar of Metaphor (1958), A ZBC of Ezra Pound (1971), and, perhaps most importantly, A Rhetoric of the Unreal: Studies in Narrative and Structure, Especially of the Fantastic (1981) as well as Stories, Theories, and Things (1991).

3 To exemplify, in her tongue-in-cheek paper "Woman as a Semiotic Object", Brooke-Rose conducts a semiotic study of "perfect love" as "the manifestation of the relations from two groups of permutations" (1985: 10), where the analysis proper serves as a point of departure for a terse feminist commentary on the condition of women in contemporary society.
} 
she knows or happens to meet, only to retreat to the safe haven of her own home, where she remains, as Hopkins would have it, in steadfast, "eloquent silence" - her lips "lovely-dumb".

On the one hand it leads to the pervasive feelings of ennui and resignation but on the other - perhaps quite paradoxically - to the burning desire of verbalisation of those most upsetting experiences. The process is anything but simple, be it to the main character, who seeks more and more unconventional ways of articulation of her traumas, or to the reader, who is in some capacity encouraged to act as the protagonist's sole confidant ${ }^{4}$. The author, "reversing the traditional form", goes to great lengths - quite like in her earlier novel, The Dear Deceit - to make us "think like biographers rather than readers of biography" (Darlington 2014: 75), whereby one is actively incentivised to embark on an onerous task of hermeneutic co-construal of the narrative based on unstable sign interconnections. It is all the more difficult given the form of Mira's confession, which haphazardly mixes allusions to classical literature with ancient history, oftentimes referring to most obscure, arcane scientific facts or astronomical discoveries that further demand from the reader deepened knowledge of geography, medicine, mythology, narratology. It offers philosophical ruminations on the nature of human experience or a fragmentary scrutiny of interpersonal relationships as much as it presents the problematic work at academia; with academia being a very special environment in which all those elements meet and clash. According to Brooke-Rose, what appears to be the common denominator binding most of those spheres is the decline of language and the general inefficacy of linguistic means of expression at our disposal, which in turn quite pessimistically hints at the possible decline of mankind and human civilisation.

Indeed, this noticeable concern for language, and, conversely, a lack of concern for people, were an issue that many scholars focused on upon the publication of the novel in 1984. In one of the early reviews in The New York Times, the critic playfully referred to Amalgamemnon as a "revillusionary punorama", which, "like so much of postmodern literature, takes a self-delighting, linguistic turn. That is, fiction, which has always attended to language, now makes it the center of its reflexive concern, and explodes in ludic, parodic, ironic forms. It is carnival time for the Logos" (Hassan 1985: 20). And just like in the carnival, which seems to be in some way a metaphor really befitting the novel, Amalgamemnon overturns hierarchies and mingles the sacred with the profane, the sublime with the ridiculous, but also the gravitas that academia sometimes evokes with the banality of everyday life. Both ends of the spectrum are equally important, but both may just as well be satirised, and this is precisely what Brooke-Rose does here and in a number of her other publications, not only feeding into but drawing from the "transnational transit and cultural confusion" (Darlington 2014: 72) typical of literature of that time. In a distinctively carnivalesque fashion, she also turns inside out the linguistic layer of the text, purposefully breaking conventional causal and intersemiotic relationships, where an anomaly becomes a norm, and a norm - an anomaly.

Being a female university teacher and a writer herself, Brooke-Rose had a vast pool of experiences to draw from. In fact, as she states outright in one of her critical pieces, "it

\footnotetext{
${ }_{4}$ In this sense, the novel may be partially interpreted as a fictional testimonial narrative, giving the voice to a woman deprived of what she has always held dear, effectively making her somewhat of a castaway in her own community. "[B]eing a witness to oneself" (Laub 1992: 75), she eventually has to address what "could not be articulated" (85) to reclaim her very subjectivity and agency, and to finally move on.
} 
seems to me that the combination of woman + artist + experimental means so much hard work and heart-break and isolation that there must be little time or energy for crying out loud" (Brooke-Rose 1989: 65-66). This listlessness she experienced as a writer-cum-academic who found widespread acceptance neither from conventional male reviewers nor from feminist critics, only exacerbated her isolation, to the point where she felt "she is in the sea between two continents" (ibid.: 67), with her deliberately tortuous writing being somewhat of a bete noire both in the US and the UK ${ }^{5}$.

Restrained by her life circumstances and social mores of the time, the author also very subversively tried to restrain her fiction to the point where self-imposed linguistic limitations became precis ely a new locus of meaning - something that generated new stories instead of keeping her creative endeavours in check. In fact, she appears to have thrived while writing under very limiting formal constraints. For instance, in her 1968 novel Between, she penned the whole narrative without the verb "to be". The same can be observed in her other text, simply called Next, wherein she did not use the verb "to have". In both cases she proved that women, even when silenced and denied the right to be and to possess, can still prosper in a number of ways that disregard androcentric or phallogocentric ideologies dominant both in and outside academia. In Amalgamemnon Brooke-Rose may be said to have gone one step further insofar as the conceit she chose is much more restrictive - the whole text is a first-person confession written only in future and conditional tenses, with a sporadic use of imperative and subjunctive moods. "The idea", says the author, "was to avoid all constative sentences, of which it can be said that they are true or false. [...] So nothing can ever be said to be 'really' happening, or to be 'true.' It's in fact a thorough exploration of the performative, excluding the constative" (Seed 1993: 254).

The formal conceit feeds very efficaciously into the thematic complexity of the novel. That is, what initially seems to be a rant of a frustrated academic turns out to be a mockprophecy. With time it becomes apparent that the character of Mira may in actuality be a cursed Greek prophetess Cassandra - the princess of Troy, one that was known for her beauty and charm, both of which eventually drew the admiration of Apollo. In his attempt to win her heart, he offered the girl a gift of divination and retrocognition - promising her she would be able to peer deep into the future and into the past. She readily accepted the favour but was unwilling to reciprocate the god's feelings in return, at which point, shunned by a mere mortal, indignant Apollo cast a curse on the girl, saying that even though her prophecies would always be true, no one would ever believe a word that came from her mouth. Thus, Cassandra is doomed insofar as she augurs her final demise but cannot do anything that would preclude a chain of events which ultimately leads to her own death. People accuse her of lunacy, she is raped and violated, and subsequently taken as a concubine by Agamemnon, King of Mycenae. Agamemnon is sometimes portrayed as the epitome of virility but also as a brutal oppressor and tyrant.

${ }^{5}$ Being fully cognisant of the lukewarm, sometimes even hostile, reception, Brooke-Rose seems to fully embrace the apparent difficulty and impenetrability of her fiction: "I don't apologize for that at all. One of my aims in writing the way I do is to teach people to read. They have forgotten how to read. I want what Barthes calls the writerly text as opposed to the readerly text - the readerly text is the consumer product, which can be flicked through. I'm not against that - to read on the train or in the bath. But where is the pleasure of reading if, in fact, you're just going to skip things such as description?" (Friedman [\&] Fuchs 1989: 88). 
In this sense, the characters from the myth serve as a perfect foil to the downtrodden Mira and her partner, who mistreats her as much as Agamemnon mistreated Cassandra. Mira, just like the ancient seeress, finds herself in a very peculiar position, where her words seem to mean nothing, and whatever she does, she cannot change her fate ${ }^{6}$. She peers deep into the past as a university lecturer teaching Greek literature. She also predicts the future in the sense that she foresees the end of her career, but just like Cassandra foreseeing her death, she can only wait for the end to come. Mira barely speaks - she can, though, "proffersigh" or utter an occasional "hexpression" (Brooke-Rose 1984: 53, 126). Those interesting neological coinages deftly characterise the protagonist's condition, conjoining dichotomies she faces on a daily basis: those between verbalisation and silence, between aporia and selfarticulation. Instead of actually prophesying, she "proffers sighs", and, as if under a hex, Mira's desire to express her feelings and thoughts comes to naught: regardless of what does and does not transpire, the ill-fated prophetess is doomed to fail. To prepare herself for the final blow and better internalise everything that happens to her, she weaves her experiences into a narrative, mentioning her work at university, her interactions with her students, but also some of her fantasies. For example, at one point she considers venturing into pig farming, which perhaps might be read as a subtle nod towards the figure of Circe, who - as one can read in Homer's Odyssey - transformed Odysseus's ship's crew into swines, something that Mira would perhaps like to do herself to all the men who harass her had she some sort of magical power. Instead, what she does is she attempts to distance herself as much as possible, just like in the following passages in which she refers to William, her partner. They present a couple sharing an intimate moment together, whereupon the man falls asleep; the woman goes to the living room to read, and then next morning they engage in a bit of a conversation:

Soon he will come. There will occur mimecstasy even if millions of human cells remain unconvinced and race around all night on their multiplex business, transmitting coded information, most of it lost for ever.

Soon he will snore, in a stentorian sleep, a foreign body in bed. There will occur the blanket bodily transfer to the livingroom for a night of utterly other discourses that will crackle out of disturbances in the ionosphere into a minicircus of light upon a page of say Herodotus and generate endless stepping-stones into the dark, the Phoenicians kidnapping Io and the Greeks in Colchis carrying off the king's daughter Medea, creating in advance as yet another distance which I'll have carefully to deconstruct tomorrow by letting him abolish all those other discourses into an acceptance of his, although sooner or later the future will explode into the present despite the double standard at breaking points. (Brooke-Rose 1984: 15-16)

Tomorrow at breakfast Willy will pleased as punch bring out as the fruit of deep reflection the non-creativity of women look at music painting sculpture in history and I shall put on my

6 The point is emphasised on a number of occasions with regards to ever-developing and dehumanising technology. As a professor of classics, Mira Enketei anticipates that she (and those passionate about her discipline) might one day be replaced by computers and electronic machines. She even fears that "[t]he very foetus will be programmed into a prophetus curling up in the womb with a book of genetic information" (1984: 83). Brooke-Rose may be said to have voiced and assumed a strong political stance on the topic, criticising a blind desire for human self-improvement and eugenics, "hurtling into the black and endless void" the entirety of mankind, which one day may"dream of the diminishing cat unfed and fatally developing to a foetal dedevelopment, to be spawned on a lonely shore in noman's promised land and write in a helpless wriggle of forming fins its cybernetic story on the sand and away" (1984: 82). 
postface and mimagree, unless I put on my preface and go through the routine of certain social factors such as disparagement from birth the lack of expectation not to mention facilities a womb of one's own a womb with a view an enormous womb and he won't like the countertone at all, unless his eyes will be sexclaiming still [ ... ]. (ibid.: 16-17)

Both fragments are most typical of Amalgamemnon's style, characterised by verbal flair, linguistic dexterity, acerbic humour, as well as anacoluthic syntax. References to the sorceress Medea, and the abducted Io, and Virginia Woolf's "A Room of One's Own", or E. M. Forster's A Room with a View, as opposed to the man's "sexclamations" in the morning are not accidental - they all allude to a choir of powerful women, singing in unison despite having been subjugated by a polyphony of phallogocentric voices dominant in the history, politics, mythology, and, more broadly, cultural heritage of the West - very often mediated by academia ${ }^{7}$. Tracing and contextualising all those defamiliarised voices is not an easy task, but that in and of itself also seems to be the point:

People want the familiar. They want to be sécurisé, as the French say. They want to be made secure, they want to be made to recognise everything. It's the pleasure of recognition, not the pleasure of discovery. I prefer the pleasure of discovery. Now it does sometimes make it tough. (Brooke-Rose qtd. in Pohl 2018: 288)

Mira's description goes on and on; it is an enumeration, not to say an amalgamation, of different things presented in this stream-of-consciousness-like manner, where it can be truly seen and appreciated how "the chameleonic nature" of Brooke-Rose's narrative "is equally its mercurial characteristic, constantly requiring the reader to shift attention between the internal and external planes of the text for its limitless semiosis" (Bartha 2014:3). One is literally flooded with numerous references mixing the past, the present, and the future, in which way ancient myths inform the character's everyday life, thereby situating the reader in a broader interpretative field. There are multiple, though not always easily discernible, narrative levels superimposed onto one another, where Greek mythology, Mira's account, and the quasi-scientific depictions of technology blend seamlessly into one story. The by-product of this amalgamation is a very specific, idiosyncratic discourse of the novel, full of ellipses, breaks in communication, paralepses and paralipses but also of rhetorical tropes, and in particular, neologisms.

The man "sexplains" his worldview while the woman does nothing but "mimagree" or feigns "mimecstasy". The notions of mimicry and mimetic representation are omnipresent on the pages of the book. For the protagonist to "mimagree" is to mime agreement. Her reactions are as if not her own, just like in the aforementioned passage wherein she merely puts on her "preface", analyses a priori the possible outcomes of the situation, and mimics the expected behaviour accordingly. At that, the main character is fully cognisant of the artificiality of the situation, especially when she treats her partner more like a literary construct than as a person of flesh and blood: "If he were someone in a nineteenth-century novel

\footnotetext{
7 The idea is explored further by Karen R. Lawrence, who finds Brooke-Rose's protagonist reading The Histories penned by Herodotus particularly poignant and significant - engaging with the thought of the Halicarnassian historian, she indirectly engages with "the violence against women in classic history, not only physically, but psychically, with the loss of their voices" (2010: 103).
} 
I might ironically detach him" (Brooke-Rose 1984: 7), says the woman flippantly. Mira tries to portray the reality on her own terms in a desperate attempt to preserve her identity, which she considers the only logical solution. "[T] he young Scythians will be unable to learn the language of the Amazons but the women will succeed in picking up theirs, and therefore disappear" (ibid.: 141). In this case, to adopt a typically phallogocentric discourse means to evanesce - to cease to be. And in the novel this conviction is only exacerbated by William; for example in the following statement: "Sandra my love of course I will he'll exclaim, and we'll celebrate when you'll be rid of the university, when thanks to me you will accept, and face, being only a wo man" (ibid.: 15). Two points particularly worthy of comment, minus the extremely sexist remark, are the fact that he surprisingly addresses her as Sandra, that is Cassandra, and the multiplicity of the word "will", a hypocoristic form for William which the text is always rife with every time he speaks: I will, he will, we will, you will - Will, i.e. William the character, is always present in the narrative, especially given the abundance of future tense markers. Mira is as if in his thrall, and she can never escape his smothering influence, which by extension may be treated as a scathing commentary on the social status of women in society and in academia.

As is probably apparent at this point, the linguistic experimentation in the novel is of paramount importance. One might even be tempted to posit, as put forward by JeanJacques Lecercle, that

The real narrator is not Cassandra, but language itself, or rather that part of language that speaks the speaker, the remainder. [... ] Each word becomes a character who calls and answers other words, establishing a network of relationships that sustains the text, evokes voices, and creates a world. (1990: 96)

Indeed, the language may be in some capacity interpreted as one of the main characters in the story, and its nebular network of complex interconnections - as a semblance of an equally nebulous character constellation. Although the concept itself is hardly original, the very opening of the novel seems to invite such an interpretation. The text begins with the following sentence: "I shall soon be quite redundant at last despite of all, as redundant as you after queue and as totally predictable, information-content zero" (BrookeRose 1984: 5). The redundancy implied is also visible in the constant use of "oracular future tenses" and the subjunctive mood that on the one hand look forward to events but on the other preclude their realisation. Everything may just as well be mentioned in the discursive space of the novel, yet nothing actually transpires; actions, characters, concepts belong to the realm of the feasible but imperfective and indeterminative. The opening sentence of Amalgamemnon echoes the beginning of Beckett's Malone Dies: "I shall soon be quite dead at last in spite of all" (1956: 1). Both begin with an "I" that may just as well apply to the narrative or to the protagonist; both, too, are confronted with their futility and uselessness. "Despite of all" in the first opening and "in spite of all" in the second very clearly imply that all efforts notwithstanding, be it on the part of the reader or of the author, the text will become redundant once perused, and its potential - fully exhausted.

That is why Mira feels as redundant as <u $>$ after <q $>$ ("you after queue" [1984: 5]). As a subservient phoneme and in its function as a bound morpheme, [u] does not really have independent existence; it is just merely phonetically conditioned based on 
a well-established linguistic convention. It other words, in and of itself it may just as well be virtually non-existent. Or just like in the quote: its information content equals zero. Once applied to the main character, it is a most bleak and heart-breaking self-portrayal, where one actually doubts the very sense of their own existence that is shaped, conditioned, and restricted by others, and where one's own voice does not really matter. Perhaps that is also why Mira, to better cope with this burden, tries to project her persona onto other people, predominantly Cassandra, distorting original references to the actual Agamemnon by Aeschylus, wherein the ancient tragedian really drives the point home quite successfully while portraying Cassandra's histrionics:

$\begin{array}{ll}\text { Kassandra: } & \text { Otototoi O Earth! Earth! } \\ \text { Chorus: } & \text { Why upon Loxias callest thou thus woefully? } \\ & \text { He is not one who needeth dirgelike litanies. } \\ \text { Kassandra: } & \text { Otototoi O Earth! Earth! O Apollo! O Apollo! } \\ \text { Chorus: } & \text { Once more with ill-omened cries she calls that God } \\ & \text { Whose ears by lamentations are profaned. (1920: 38) }\end{array}$

In Amalgamemnon by Brooke-Rose, the words are simplified - merely an echo of the original exchange: "Cassandra princess of fallen Troy who will exclaim alas, o earth, Apollo apocalyptic and so forth" (1984: 5). Thus presented, especially in comparison, the allusion seems to be quite dismissive of the original text. To account for it, one could probably say that is was merely recalled from memory by the protagonist, who might have taught Aeschylus's tragedies to her students during one of her classes. But what matters the most and what undeniably strikes the reader is marked lassitude on the part of the character. She is so drained and resigned she cannot even verbalise normally what Cassandra in the ancient play would nearly scream out loud in full voice.

This very evident referentiality might also be interpreted as one mode of characterial (auto)creation. In many of Brooke-Rose's works, and in Amalgamemnon in particular,

narration unfolds as a never-ending process of substitution by which referential reality is for ever named and yearned for but never grasped, or else is made present through an exhibition of its utter unsubstantiality. Characters themselves become part of a continual rehandling of signifiers, existing as they do only through a game of reciprocal invention of one another: a sort of game within which they come alive and disappear as an effect of a capricious, mutual reinvestment of a never fulfilled desire. (Del Sapio Garbero 1994: 94)

The self-suppression and subsequent substitution are at the core of Mira Enketei's problematic self-portrayal. As an academic with a wealth of experience and a genuine interest in ancient history and literature, she has the whole gamut of resources to use while "re-writing" her own persona, in which sense - by extension - the text can be of interest to quite a broad readership: to historians, philosophers, anthropologists, semioticians, theoreticians of culture, and linguists. The wealth of resources notwithstanding, naturally one more significant element of the narrative and a powerful meaning-laden device is the use of silence: silence traceable in its many gaps and lacunae; silence necessitated by exclusion and deletion. It proves that reality (especially: the intratextual reality of the novel) is not just a passive matrix of objects, persons, or experiential states that constitute or influence 
the characters, but that its deeper significance can be also unearthed from the peripheries of discourse, from "between the lines", where the vestiges of meaning can tell the reader more than what is verbalised outright ${ }^{8}$. Even then, the task at hand is never easy - yet such is the main character's lot and that is what she does, for "it always be the fate of seers to utter idées by definition reçues from everysomewhere suspended in some black cloud of news enveloping the earth and ever replenished $[\ldots]$ that will change while passing through the minds of their observers, seers, readers, cyberneticians, historians, pigfarmers and such" (Brooke-Rose 1984: 78). And, by extension, such is our lot as readers to trace and analyse those ideas that pass through our minds as well as those that subversively elude us, not only to help the characters co-construct the intratextual worlds of the novels they inhabit but also to add to our own experience and enrich our own lives.

\section{Bibliography}

Aeschylus 1920. The Oresteia of Aeschylus: Agamemnon, Choephori, Eumenides. Translated by

R. C. Trevelyan. Cambridge: Bowes \& Bowes.

Bartha, Noemi Alice 2014. Christine Brooke-Rose: The Chameleonic Text Between Self-Reflexivity and

Narrative Experiment. Newcastle upon Tyne: Cambridge Scholars Publishing.

Beckett, Samuel 1956. Malone Dies. New York: Grove Press.

Brooke-Rose, Christine 1984. Amalgamemnon. Manchester: Carcanet.

1985. "Woman as a Semiotic Object". Poetics Today 6, 1/2: 9-20.

— 1989. "Illiterations". In: Ellen G. Friedman [\&] Miriam Fuchs (eds.). Breaking the Sequence: Women's Experimental Fiction. Princeton: Princeton University Press.

2009. Stories, Theories, Things. Cambridge: Cambridge University Press.

2012. A Rhetoric of the Unreal: Studies in Narrative e' Structure, Especially of the Fantastic. Cambridge: Cambridge University Press.

Darlington, Joseph Andrew 2014. "Everything You Always Wanted to Know about Christine Brooke-Rose's Distant Relatives (But Were Too Poststructuralist to Ask)". In: G. N. Forester [\&] M. J. Nicholls (eds.). Verbivoracious Festschrift Volume One: Christine Brooke-Rose. Glentrees: Verbivoracious Press.

Del Sapio Garbero, Maria 1994. “The Fictionality of Fiction: Christine Brooke-Rose's Sense of Absence". In: Theo D’haen [\&] Hans Bertens (eds.). British Postmodern Fiction. Amsterdam: Rodopi.

Fish, Stanley 1980. “What Makes an Interpretation Acceptable?”. Is There a Text in This Class? The Authority of Interpretative Communities. Cambridge, MA: Harvard University Press.

Friedman, Ellen G. [\&] Miriam Fuchs 1989. "A Conversation with Christine Brooke-Rose". Review of Contemporary Fiction 9, 3: 81-90.

Hassan, Ihab 1985. "Revillusionary Punorama”. The New York Times, 8 September 1985, section $7: 20$.

Kalaga, Wojciech H. 1997. Nebulae of Discourse: Interpretation, Textuality, and the Subject. Frankfurt am Main: Peter Lang.

\footnotetext{
8 Since comprehension and, perhaps even more so, thought can, after all, be "broadly defined as a signrelating process" (Wykoff 1970: 59), one needs to be mindful of the paraverbal and the elliptical, which, too, contribute both to the infinite chain of semiosis, "existentially - in its potentiality - rooted in relations" (Kalaga 1997: 90), and to the interpretation.
} 
Laub, Dori 1992. "An Event Without a Witness: Truth, Testimony and Survival". In: Shoshana Felman [\&] Dori Laub (eds.). Testimony: Crises of Witnessing in Literature, Psychoanalysis, and History. New York and London: Routledge.

Lawrence, Karen R. 2010. Techniques for Living: Fiction and Theory in the Work of Christine BrookeRose. Columbus: The Ohio State University Press.

Lecercle, Jean-Jacques 1990. The Violence of Language. New York: Routledge.

Pohl, Rebecca 2018. "Selling Difficulty: The Case of Christine Brooke-Rose". Textual Practice 32, 2: 283-299.

Seed, David 1993. "Christine Brooke-Rose Interviewed by David Seed”. Textual Practice 7, 2: 247257.

Wykoff, William 1970. “Semiosis and Infinite Regressus”. Semiotica 2, 1: 59-70. 